\title{
INTEGRACJA POLSKIEGO RYNKU PAPIERÓW UDZIALOWYCH Z RYNKAMI ZAGRANICZNYMI A WZROST GOSPODARCZY W POLSCE
}

\begin{abstract}
Streszczenie. Celem artykułu jest odpowiedź na pytanie: czy integracja polskiego rynku udziałowych papierów wartościowych wpływa na wzrost gospodarczy w Polsce? Sformułowano hipotezę badawczą, że integracja polskiego rynku udziałowych papierów wartościowych wpływa w sposób statystycznie i ekonomicznie istotny na rozwój rynku kapitałowego oraz wzrost gospodarczy. Jako wskaźnik integracji polskiego rynku papierów udziałowych z rynkami zagranicznymi przyjęto stosunek sumy polskich inwestycji portfelowych w udziałowe papiery wartościowe za granicą oraz zagranicznych inwestycji portfelowych w udziałowe papiery wartościowe w Polsce do PKB. Badania z zastosowaniem modeli ekonometrycznych wykazały, że wzrost stopnia integracji polskiego rynku udziałowych papierów wartościowych z zagranicą wywiera pozytywny i dość znaczny wpływ zarówno na rozwój rynku akcji, jak i na wzrost gospodarczy w Polsce.
\end{abstract}

Slowa kluczowe: integracja finansowa, papiery wartościowe udziałowe, wzrost gospodarczy, Uogólniona Metoda Momentów (UMM), model ekonometryczny.

\section{WPROWADZENIE}

Celem badań, których wyniki zostały zaprezentowane w niniejszym artykule, była próba weryfikacji teorii, która mówi o istotnym związku między integracją rynków finansowych w skali międzynarodowym, rozwojem finansowym i wzrostem gospodarczym. Przedmiotem badań nie był cały rynek finansowy, ale segment udziałowych papierów wartościowych (akcje i certyfikaty inwestycyjne). Badania ograniczono też do polskiego rynku papierów wartościowych i jego integracji z rynkami zagranicznymi oraz wpływu stopnia tej integracji na rozwój finansowy i wzrost gospodarczy. Sformułowano hipotezę badawczą, że integracja polskiego rynku udziałowych papierów wartościowych wpływa w sposób statystycznie i ekonomicznie istotny na rozwój rynku kapitałowego oraz wzrost gospodarczy. Za miarę integracji rynku udziałowych papierów wartościowych przyjęto stosunek sumy polskich inwestycji portfelowych w udziałowe papiery

* Uniwersytet Technologiczno-Humanistyczny im. Kazimierza Pułaskiego w Radomiu, Wydział Ekonomiczny, Katedra Biznesu i Finansów Międzynarodowych. 
wartościowe za granicą oraz zagranicznych inwestycji portfelowych w udziałowe papiery wartościowe w Polsce do PKB. Za miarę stopnia rozwoju rynku kapitałowego przyjęto stosunek kapitalizacji giełdowej na rynku akcji do PKB. Miarę tę potraktowano również jako jedną z miar rozwoju finansowego. W badaniach zastosowano dwa modele ekonometryczne estymowane przy pomocy uogólnionej metody momentów (GMM).

\section{INTEGRACJA RYNKÓW FINANSOWYCH A WZROST GOSPODARCZY W ŚWIETLE TEORII I BADAŃ}

L. Baele, A. Ferrando, O. Hördal, E. Krylova, C. Monnet (2004: 6-7) zaproponowali szeroką definicję integracji rynków finansowych. Wynika z niej, że rynki akcji są zintegrowane, jeśli wszyscy potencjalni uczestnicy transakcji o jednakowych cechach:

- podlegają tym samym regułom, gdy zdecydują się na uczestnictwo w obrocie akcjami,

- mają jednakowy dostęp do akcji,

- są traktowani jednakowo, gdy działają na rynku.

Jest to definicja szersza niż te oparte na prawie jednej ceny. Pozwala również na zastosowanie wskaźników ilościowych jako miar integracji rynków finansowych, które w przeciwieństwie do wskaźników opartych na prawie jednej ceny są bardziej przydatne do badań nad związkiem integracji finansowej i wzrostu gospodarczego ze względu na swoją zmienność w czasie ${ }^{1}$.

Efekty międzynarodowej integracji rynków finansowych związane są z oddziaływaniem procesów integracyjnych na wzrost gospodarczy oraz stabilizację lub destabilizację gospodarczą.

Pierwsze zagadnienie jest związane z problematyką rozwoju finansowego i związków między rozwojem finansowym a wzrostem gospodarczym.

Rozwój finansowy pojawia się wówczas, gdy instrumenty finansowe i pośrednicy finansowi polepszają efekty informacji, zwiększają dyscyplinę uczestników rynku finansowego i zmniejszają koszty transakcyjne oraz w ten sposób powodują, że lepiej jest realizowanych pięć funkcji:

a) dostarczania informacji ex ante o możliwych inwestycjach i alokacja kapitału;

b) monitorowania inwestycji i wzmacniania ładu korporacyjnego (corporate governance);

c) ułatwiania handlu instrumentami finansowymi, dywersyfikacji ryzyka i zarządzania ryzykiem;

d) mobilizacji i gromadzenia oszczędności;

e) ułatwiania wymiany towarów i usług.

Każda z tych funkcji może wpływać na decyzje o oszczędzaniu i inwestycjach, a stąd na wzrost gospodarczy (Levine 2004: 5-7).

\footnotetext{
${ }^{1}$ Na temat szerzej: Bukowski (2011: 32-55), Coricelli i in. (2008), Sum (2012).
} 
Jak wynika z powyższego fragmentu, rozwój finansowy to przede wszystkim zmiany o charakterze jakościowym. Funkcje te są wypełniane przez rynki finansowe i pośredników finansowych. W długim okresie realizacja owych funkcji prowadzi do wzrostu akumulacji kapitału. Ponadto poprzez tworzenie możliwości dla dywersyfikacji ryzyka i kreowanie źródeł finansowania stymulują wzrost innowacji technologicznych. Razem, stymuluje to wzrost gospodarczy (Bukowski 2011: 26).

Według R. Levine'a wpływ rozwoju finansowego na wzrost gospodarczy odbywa się według schematu przedstawionego na rys. 1 .

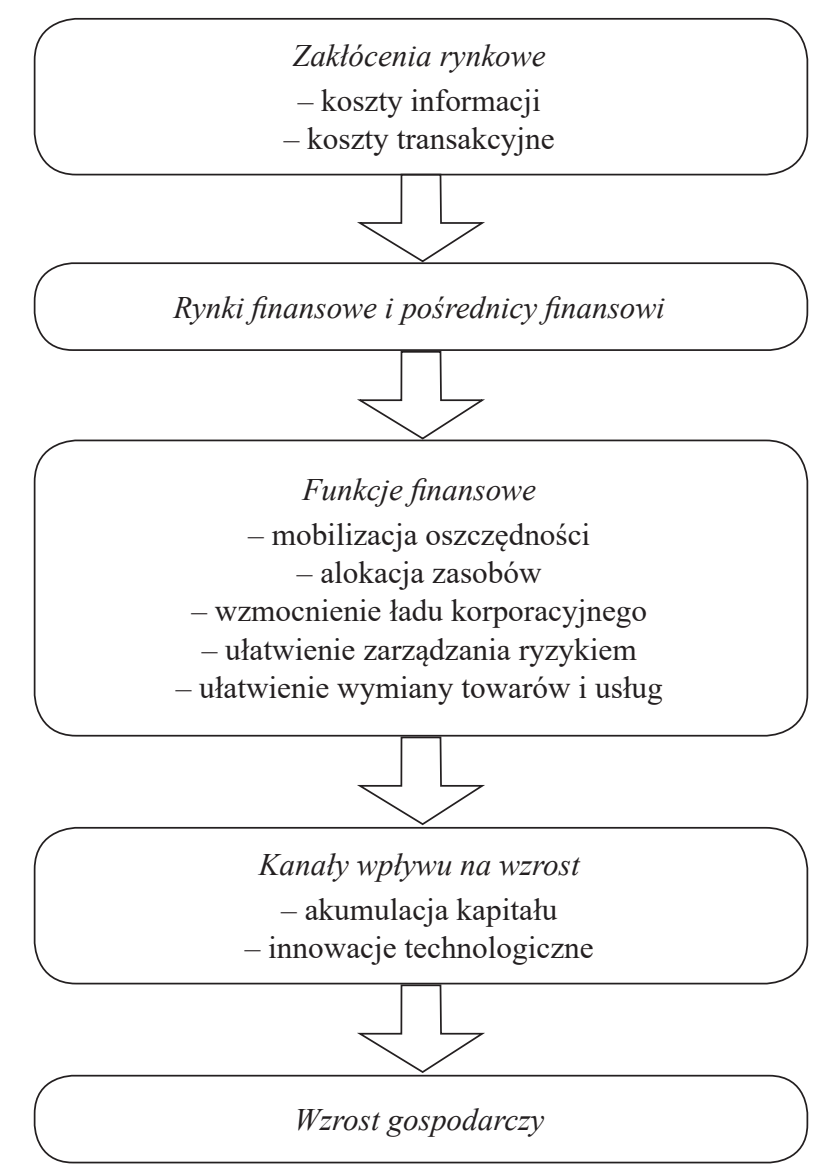

Rys. 1. Teoretyczny związek między finansami i wzrostem gospodarczym

Źródło: Levine (1997: 691).

Warto podkreślić, że zależność między rozwojem finansowym, w szczególności rynkami finansowymi, a wzrostem gospodarczym nie jest jednoznaczna zarówno z punktu widzenia teoretycznego, jak i z punktu widzenia wyników badań 
empirycznych opartych na różnych metodach ekonometrycznych. J. Robinson twierdziła, że finanse podążają za rozwojem przedsiębiorstw (,where enterprise leads, finance follows") (por. Robinson 1952: 80). R. Lucas (1988) też podawał w wątpliwość związek między rozwojem finansowym a wzrostem gospodarczym, twierdząc, że jeśli związek taki istnieje, to zapewne rola finansów we wzroście gospodarczym jest przesadzona.

Inni autorzy wskazują na równoległość i współzależność rozwoju rynków finansowych i wzrostu gospodarczego. Według J. Greenwooda i B. Jovanovic (por. 1989: 25) wzrost gospodarczy dostarcza środków, dzięki którym rozwijają się rynki finansowe i pośrednictwo finansowe, a proces ten z kolei przyspiesza wzrost gospodarczy poprzez wspomaganie alokacji kapitału. Tego typu pogląd w znacznej mierze potwierdzają także badania empiryczne (zob. szerzej: Bukowski 2011: 29-32).

W Polsce badania dotyczące wpływu rozwoju rynków finansowych na wzrost gospodarczy prowadzili: W. Dębski, I. Maciejczyk, P. Wdowiński (2010), W. Dębski, I. Bujnowicz (2008) i S. I. Bukowski (2011; 2013). Wyniki ich badań wskazują na statystycznie istotną i zgodną z teorią dwustronną zależność między rozwojem rynków finansowych, a przede wszystkim rynku akcji, a wzrostem gospodarczym w Polsce i w przypadku badań S. I. Bukowskiego (2011) - w obszarze euro.

Zależność między rozwojem samych rynków finansowych a wzrostem gospodarczym w długim okresie przedstawia się następująco. Rozwój rynków finansowych jest składową szeroko pojętego rozwoju finansowego. Z jednej strony rozwój finansowy znajduje wyraz we wzroście wartości określonych zmiennych ilościowych charakteryzujących zmiany na rynku finansowym i w systemie bankowym, do których można zaliczyć m.in: wzrost liczby banków na 1000 mieszkańców, wzrost wartości aktywów bankowych w relacji do PKB, wzrost wartości kredytów bankowych w relacji do PKB, wzrost kapitalizacji giełdowej do PKB, wzrost liczby spółek publicznych (których akcje są notowane na giełdzie), wzrost ilości nowych emisji instrumentów finansowych. $Z$ drugiej strony o rozwoju finansowym można mówić również wówczas, gdy zachodzą określone zmiany jakościowe, np. wprowadzanie nowych produktów bankowych i innowacji finansowych, wzrost skłonności podmiotów gospodarczych do lokowania oszczędności w nowych produktach finansowych oraz korzystania z nowych usług finansowych, pojawienie się nowych wyspecjalizowanych instytucji finansowych, zaspokajających nowe potrzeby rynku, łączenie i przenikanie się oddzielnych do niedawna rodzajów działalności finansowej i usług finansowych (np. bankassurance), konsolidacja instytucji finansowych i ich internacjonalizacja (zob. Bukowski 2011: 26 i n.).

Integracja rynków finansowych $\mathrm{w}$ skali międzynarodowej oddziałuje na wzrost gospodarczy poprzez stymulowanie rozwoju finansowego (w tym rynków finansowych), co ilustruje rys. 2.

L. Guiso, T. Japelli, M. Padula, M. Pagano (2004: 6-30) wykazali na podstawie wyników badań symulacyjnych, że zwiększenie stopnia integracji finansowej w krajach UE do poziomu właściwego dla USA lub do maksymalnego poziomu, 
jaki występuje w danym kraju UE-15, prowadzi do wzrostu wartości dodanej, produkcji przemysłowej w całej UE-15. Efekty wzrostowe oczywiście będą różne w przypadku poszczególnych krajów i sektorów. Według nich kraje o względnie słabszych strukturach finansowych będą korzystały bardziej na integracji rynków finansowych niż kraje o względnie wysokim poziomie ich rozwoju.

Integracja rynków finansowych w skali międzynarodowej wpływa na rozwój lokalnych rynków finansowych poprzez wzrost inwestycji w sektorze finansowym i zwiększenie głębokości rynków finansowych. Ponadto wraz z napływem inwestycji bezpośrednich do sektora finansowego następuje wzrost konkurencji w tym sektorze oraz wzrost efektywności instytucji finansowych (napływ nowych technologii). Presja konkurencyjna prowadzi do redukcji negatywnej selekcji (adverse selection) i kosztów pośrednictwa finansowego (financial agency costs), wzrostu stopnia dostępności kapitału dla przedsiębiorstw i gospodarstw domowych. Poprawa dostępności kapitału dla przedsiębiorstw i gospodarstw domowych następuje również poprzez dostęp do szerokiego międzynarodowego rynku finansowego.

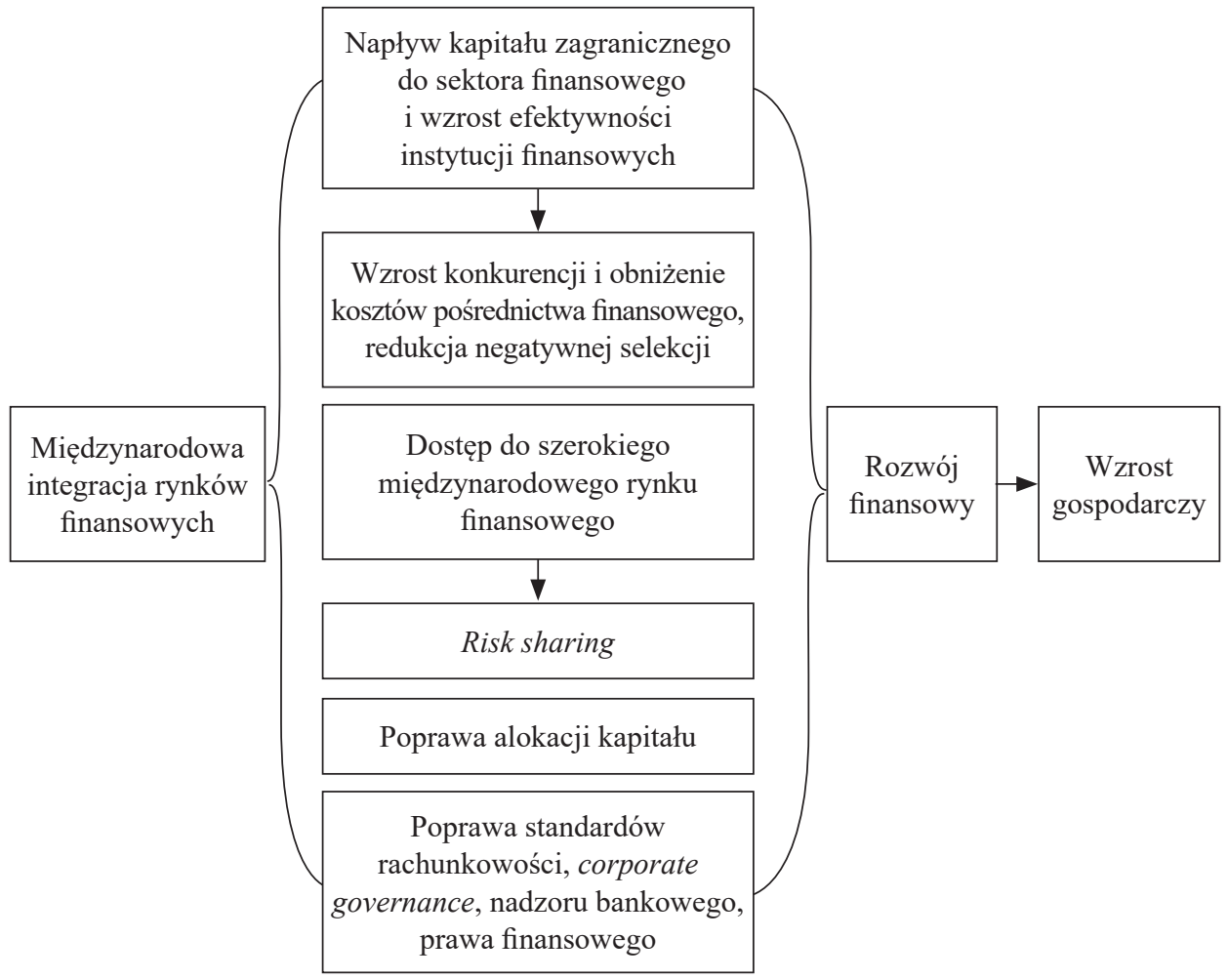

Rys. 2. Teoretyczny związek między międzynarodową integracją rynków finansowych a rozwojem finansowym i wzrostem gospodarczym

Źródło: Bukowski (2011: 35). 
F. Coricelli, A. Brezigar Masten, I. Masten (2008) badali wpływ integracji finansowej na rozwój finansowy i wzrost gospodarczy. W badaniach zastosowali m.in. następujący model:

$$
\Delta y i t=\alpha i+\rho \Delta y i, t-1+\beta I F I i t+\gamma, X i t+\delta t+u i t,
$$

gdzie: $\Delta y i t$ - tempo wzrostu realnego PKB per capita; $\beta$ IFIit - wektor miar międzynarodowej integracji finansowej (zagraniczne aktywa i zobowiązania/PKB, zobowiązania wobec zagranicy/PKB, wartość napływu i odpływu zagranicznych inwestycji bezpośrednich d/PKB, zagraniczne inwestycje bezpośrednie/PKB); Xit - wektor zmiennych kontrolnych (bezpośrednie inwestycje zagraniczne/PKB, kapitalizacja giełdowa/PKB, kredyt dla przedsiębiorstw/PKB, stopa inflacji i inne).

Badaniami objęto kraje UE-27, Chorwację, Islandię, Norwegię, Rosję i Ukrainę oraz okres 1996-2006. Dane pochodziły w części z Lane and Milesi-Ferretti data set (2006), częściowo z baz Banku Światowego. Model estymowano przy pomocy GMM.

Analiza wyników estymacji modelu potwierdziła pozytywny wpływ na wzrost gospodarczy zarówno rozwoju finansowego, jak również integracji finansowej. Ponadto, autorzy wykazali, że wpływ integracji finansowej na wzrost gospodarczy jest zależny od takich czynników właściwych dla poszczególnych krajów, jak: poziom rozwoju narodowych rynków finansowych, stabilność makroekonomiczna, jakość instytucji.

K. Sum (2012) przeprowadziła badania obejmujące 69 krajów i obejmujące dane roczne z okresu 1975-2007. Za miarę integracji finansowej jako główną zmienną objaśniającą wzrost gospodarczy w modelu przyjęła stosunek zobowiązań zagranicznych ogółem do PKB. Uzyskane wyniki ukazują rozbieżności między teorią wskazującą na pozytywny i istotny ekonomicznie wpływ integracji finansowej na wzrost gospodarczy, ale ich potwierdzenie, jak twierdzi, wymaga dalszych badań.

Ch. Friedrich, I. Schnabel, J. Zettelmeyer (2010) zastosowali w badaniach metodologię R. G. Rajan i L. Zingales (1998) opartą na badaniu wpływu integracji finansowej i rozwoju finansowego na wzrost produkcji w gałęziach gospodarki. Badaniami objęli kraje rozwijające się zaliczane do grupy emerging markets oraz dane z okresu 1998-2005. Jako miary integracji finansowej przyjęli stosunek sumy aktywów zagranicznych i zobowiązań zagranicznych ogółem do PKB, stosunek długu zagranicznego do PKB, stosunek bezpośrednich inwestycji zagranicznych do PKB. Wykazali w oparciu o analizę wyników estymacji modeli ekonometrycznych, że wpływ integracji rynków finansowych na wzrost gospodarczy jest nie tylko statystycznie istotny, lecz także ekonomicznie bardzo ważny.

Warto zauważyć, że analiz wpływu integracji rynków finansowych na wzrost gospodarczy jest niewiele. Ponadto, podobnie jak w pracach autorów przytoczonych powyżej, w większości analiz wykorzystywane są miary integracji finansowej oparte na ilościach (quantity based measures). 


\section{DANE STATYSTYCZNE}

W badaniach wykorzystano dane roczne, w tym roczne wskaźniki kapitalizacji na rynku akcji do PKB z okresu 1993-2010 zawarte w bazie danych Financial structure dataset (November 2013) opracowanej przez T. Becka i E. Al-Hussainy według metodologii opisanej w A New Database on Financial Development and Structure (Beck, Demiurguç-Kunt, Levine 1999), dane z baz danych: Statistical Data Warehouse z lat 2011-2013, AMECO, EUROSTAT.

Dane dotyczące realnego PKB oraz realnych inwestycji netto pochodzą z bazy danych AMECO. Wielkości realnego PKB i inwestycji netto (NFCF) zostały oszacowane w cenach stałych z 2000 r. Wskaźnik rozwoju rynku akcji został skonstruowany przez autorów bazy danych (zob. Beck, Demiurguç-Kunt, Levine 1999) w następujący sposób:

$S T O C K$ - stosunek kapitalizacji giełdowej na rynku akcji do PKB

$$
\left\{0,5\left[\mathrm{STOCK} / P_{-} e_{t}+\mathrm{STOCK}_{t-1} / P_{-} e_{t-1}\right]\right\} / G D P_{t} / P_{-} a_{t},
$$

gdzie: $P e_{t}-$ stopa inflacji $(C P I)$ z końca roku; $P_{-} e_{t-1}-$ stopa inflacji $(C P I)$ z początku roku; $P a_{t}$-średnioroczna stopa inflacji $(C P I) ; G D P_{t}-\mathrm{PKB}$ w roku $t$; $t$ - rok.

Podobnie oszacowano ten wskaźnik dla lat 2011-2013.

Wskaźnik integracji polskiego rynku papierów udziałowych z zagranicznymi rynkami papierów udziałowych jako stosunek sumy polskich inwestycji portfelowych w papiery udziałowe za granica i zagranicznych inwestycji portfelowych w polskie papiery udziałowe do PKB wyrażono w cenach stałych z 2000 r. Dane źródłowe zaczerpnięto z bazy danych NBP (statystyka bilansu płatniczego - międzynarodowa pozycja inwestycyjna).

\section{MODEL}

Zbudowano dwa modele. Pierwszy z nich, przedstawiony poniżej, objaśnia kształtowanie się tempa wzrostu realnego PKB per capita $\left(\ln P K B_{t}\right)$ w zależności od czterech zmiennych objaśniających: wskaźnika integracji rynków papierów udziałowych - polskiego i zagranicznych ( $\left.\ln A L_{.}{ }_{t}\right)$, realnego PKB z poprzedniego okresu (zmienna opóźniona $P K B_{t-1}$ ), udziału realnych inwestycji netto w PKB $\left(N F C F_{t}\right)$, wskaźnika rozwoju rynku akcji $\left(\ln S T O C K_{t}\right)$, mierzonego jako udział kapitalizacji giełdowej w PKB.

(1) $\ln P K B_{t}=\alpha_{1 t}+\beta_{1 t} \ln A I_{t}+\gamma_{1 t} \ln P K B_{t-1}+\varphi_{1 t} \ln N F C F_{t}+\lambda_{1 t} \ln S T O C K_{t}+\varepsilon_{1 t}$ 
Drugi model objaśnia kształtowanie się kapitalizacji giełdowej w stosunku do PKB w zależności od trzech zmiennych: wskaźnika integracji rynków akcji $\left(\ln A L_{._{t}}\right)$, realnego PKB z poprzedniego okresu (zmienna opóźniona $\left.\ln P K B_{t-1}\right)$, udziału kapitalizacji giełdowej w PKB - zmiennej opóźnionej o 1 okres (lnSTOCK $\left._{t-1}\right)$.

(2) $\ln S_{T O C K}=\alpha_{2 t}+\beta_{2 t} \ln A I_{t}+\gamma_{2 t} \ln P K B_{t-1}+\varphi_{2 t} \ln S T O C K_{t-1}+\varepsilon_{2 t}$

Modele były estymowane przy pomocy uogólnionej metody momentów - dwustopniowej (2-step General Method of Moment - 2-step GMM).

\section{WYNIKI ESTYMACJI MODELU}

Tabele 1 i 2 zawierają wyniki estymacji modeli.

Tabela 1

Równanie 1: Estymacja 2-step GMM, wykorzystane obserwacje 1994-2013 (N = 20). Zmienna zależna (Y): 1_PKB_t, zmodyfikowane przez instrumenty: 1_AL_t. Instrumenty: const 1_NFCF_t

1_STOCK_t 1_PKB_t_1. Błąd standardowy HAC, szerokość okna 2 (jądro Bartletta)

\begin{tabular}{|l|c|c|c|c|c|}
\hline & Współczynnik & Błąd stand. & $\mathrm{z}$ & wartość $p$ & \\
\hline const & 1,39158 & 0,213651 & 6,5134 & $<0,00001$ & $* * *$ \\
\hline 1_AI_t & 0,966204 & 0,0680757 & 14,1931 & $<0,00001$ & $* * *$ \\
\hline Średn. aryt. zm. zależnej & $-1,834911$ & \multicolumn{5}{|c|}{ Odch. stand. zm. zależnej } & 0,888816 \\
\hline
\end{tabular}

Źródło: obliczenia własne.

Kryteria GMM: $Q=0,277931(T Q=5,55861)$ Test $J:$ Chi-kwadrat(2) $=5,55861$ [0,0621]

Test Pesarana-Taylora na heteroskedastycznosśc -

Hipoteza zerowa: heteroskedastyczność reszt nie wystęuje

Asymptotyczna statystyka testu: $z=0,609521$

$z$ wartościa $p=0,542179$

Test na normalność rozktadu reszt-

Hipoteza zerowa: skladnik losowy ma rozktad normalny

Statystyka testu: Chi-kwadrat(2) $=0,589456$

$z$ wartościa $p=0,744734$

Test LM na autokorelację rzędu 1 -

Hipoteza zerowa: brak autokorelacji sktadnika losowego

Statystyka testu: $L M F=4,39244$

$z$ wartościa $p=P(F(1,17)>4,39244)=0,0523573$ 
Test ARCH dla rzędu opóźnienia 1 -

Hipoteza zerowa: efekt ARCH nie występuje

Statystyka testu: $L M=0,00292714$

$z$ wartościa $p=P($ Chi-kwadrat $(1)>0,00292714)=0,956853$

Tabela 2

Równanie 2: Estymacja 2-step GMM, wykorzystane obserwacje 1994-2013 (N = 20). Zmienna zależna (Y): 1_STOCK_t. Zmodyfikowane przez instrumenty: 1_AL_t. Instrumenty: const 1_PKB_t

1_ STOCK $\bar{t}$ 1. Błąd standardowy HAC, szerokość okna 2 (jądro Bartletta)

\begin{tabular}{|l|c|c|c|c|c|}
\hline & Współczynnik & Błąd stand. & $\mathrm{z}$ & wartość $p$ & \\
\hline const & 26,8681 & 0,109948 & 244,3711 & $<0,00001$ & $* * *$ \\
\hline 1 1_AI_t & 0,241534 & 0,0285212 & 8,4686 & $<0,00001$ & $* * *$ \\
\hline Średn. aryt. zm. zależnej & 26,05796 & \multicolumn{2}{|c|}{ Odch. stand. zm. zależnej } & 0,246196 \\
\hline
\end{tabular}

Źródło: obliczenia własne.

Kryteria GMM: $Q=0,169751(T Q=3,39502)$ Test J: Chi-kwadrat(2) = 3,39502 [0,1831]

Test Pesarana-Taylora na heteroskedastyczność -

Hipoteza zerowa: heteroskedastyczność reszt nie występuje

Asymptotyczna statystyka testu: $z=0,934402$

$z$ wartościa $p=0,350097$

Test na normalność rozktadu reszt-

Hipoteza zerowa: składnik losowy ma rozkład normalny

Statystyka testu: Chi-kwadrat(2) $=3,6426$

$z$ wartościa $p=0,161815$

Test LM na autokorelację rzędu 1 -

Hipoteza zerowa: brak autokorelacji sktadnika losowego

Statystyka testu: $L M F=3,63642$

$z$ wartościa $p=P(F(1,17)>3,63642)=0,0746475$

Test ARCH dla rzędu opóźnienia 1 -

Hipoteza zerowa: efekt ARCH nie występuje

Statystyka testu: $L M=0,0387887$

$z$ wartościa $p=P($ Chi-kwadrat $(1)>0,0387887)=0,843868$

Istnieje statystycznie istotny związek między wskaźnikiem integracji polskiego rynku udziałowych papierów wartościowych z rynkami zagranicznymi a wzrostem gospodarczym w Polsce, a także między tym wskaźnikiem a wskaźnikiem rozwoju rynku akcji (udział kapitalizacji giełdowej na rynku akcji w PKB). Przeprowadzone testy wskazują również na prawidłowość specyfikacji i estymacji modelu. Wzrost stopnia integracji rynku udziałowych papierów wartościowych o 1 pkt. proc. powoduje wzrost PKB o 0,96 pkt. proc., zaś wskaźnika rozwoju rynku akcji o 0,24 pkt. proc. 


\section{WNIOSKI}

Wyniki przeprowadzonej w pracy analizy pozwalają stwierdzić, że wzrost stopnia integracji polskiego rynku udziałowych papierów wartościowych z zagranicą wywiera pozytywny i dość znaczny wpływ zarówno na rozwój rynku akcji, jak również na wzrost gospodarczy w Polsce. Potwierdzają one również wyniki badań innych autorów, którzy badali zagadnienia wpływu integracji rynków finansowych na wzrost gospodarczy w oparciu o modele panelowe.

\section{BIBLIOGRAFIA}

Adam K., Japelli T., Menichini T., Padula A., Pagano M. (2002), Analyse, Compare, and Apply Alternative Indicators and Monitoring Methodologies to Measure the Evolution of Capital Market Integration in the European Union, European Commision, Brussels.

Baele L., Ferrando A., Hördal P., Krylova E., Monnet C. (2004), Measuring Financial Integration in the Euro Area, „European Central Bank: Occasional Paper Series”, No. 14, April.

Beck T., Demiguc-Kunt A., Levine R. (1999), A New database on Financial Development and Structure, World Bank, Washington.

Beck T., Al-Hussainy E. (2010), Financial Structure Dataset, Revised November 2013, World Bank, Washington, D.C.

Bukowski S. I. (2011), Międzynarodowa integracja rynków finansowych, Difin, Warszawa.

Bukowski S. I. (2013), Integracja rynków finansowych w Unii Europejskiej. Czechy, Polska, Stowacja, Stowenia, Wegry - obszar euro, Instytut Naukowo-Wydawniczy Spatium w Radomiu, Radom.

Coricelli F., Brezigar Masten A., Masten I. (2008), Non-linear growth effects of financial development: Does financial integration matter?, „Journal of International Money and Finance”, No. 27, s. 295-313.

Dębski W., Bujnowicz I. (2008), Model współzależności rozwoju systemu finansowego i wzrostu gospodarczego w Polsce, „Zeszyty Naukowe Uniwersytetu Szczecińskiego. Studia i Prace Wydziału Nauk Ekonomicznych i Zarządzania”, nr 9, s. 9-20.

Dębski W., Maciejczyk I., Wdowiński P. (2010), Growth Effects of Financial Market Development in Poland: Simulations with an Econometric Model, [w:] S. I. Bukowski (red.), Global Challenges of the $21^{\text {th }}$ Century, Technical University of Radom, Publishing Office, Radom.

Friedrich Ch., Schnabel I., Zettelmeyer J. (2010), Financial integration and growth - Is emerging Europe different?, „EBRD Working Paper”, No. 123.

Greenwood J., Jovanovic B. (1989), Financial Development, Growth, and the Distribution of Income, „NBER Working Paper”, No. 3189, December.

Guiso L., Japelli T., Padula M., Pagano M. (2004), Financial Market Integration and Economic Growth in the EU, Centre for Studies in Economics and Finance, „Working Paper”, No. 118, April.

Lane P. R., Milesi-Ferretti G. M. (2006), The External Wealth of Nations Mark II: Revised and Extended Estimates of Foreign Assets and Liabilities, 1970-2004, „IMF Working Paper”, No. 69.

Levine R. (1997), Financial Development and Economic Growth: Views and Agenda, „Journal of Economic Literature", Vol. XXXV (June), s. 688-726.

Levine R. (2004), Finance and Growth: Theory and Evidence, www.econ.brown.edu/fac/Ross_levine/Publication. 
Lucas R. (1988), On Mechanism of Economic Development, „Journal of Monetary Economics”, No. 22, s. 3-42.

Rajan R. G., Zingales L. (1998), Financial dependence and growth, „American Economic Review”, 88 (3), 559-586.

Robinson J. (1952), The Generalization of the General Theory, [w:] The Rate of Interest and Other Essays, Macmillan, London.

Sum K. (2012), The integration of the financial markets and growth evidence from a global cross-country analysis, „Bank i Kredyt”, 43 (3), s. 47-70.

\title{
Stawomir I. Bukowski
}

\section{INTEGRATION OF POLISH EQUITY SECURITIES MARKET WITH FOREIGN MARKET AND ECONOMIC GROWTH IN POLAND}

\begin{abstract}
The aim of the research which is the base for this paper has been answer the question: if Polish equity securities market with foreign market influence the economic growth in Poland?

Following hypothesis was formulated: integration of Polish equity securities market with foreign market influence significantly the capital market development and economic growth in Poland. In the research applied relation between the sum of the Polish portfolio investment in the equity securities abroad and foreign portfolio investment in Polish equity securities to GDP. The econometric models were implemented in the research. The results of the research indicated that increase of Polish market of equity securities with foreign market influence positively development of capital market and economic growth in Poland.
\end{abstract} model.

Keywords: financial integration, equity securities, economic growth, GMM, econometric 